Differential distribution of constitutive heterochromatin in two species of brown spider: Loxosceles intermedia and L. laeta (Aranae, Sicariidae), from the metropolitan region of Curitiba, PR (Brazil)

\title{
Distribuição diferencial da heterocromatina constitutiva em duas espécies da aranha marrom: Loxosceles intermedia e L. laeta \\ (Araneae, Sicariidae) da região metropolitana de Curitiba, PR (Brasil)
}

\author{
RoXane Wirschum SiLVA ${ }^{1,2}$ \\ DÉbora do Rocio KLISIOWICZ ${ }^{3}$ \\ Doralice Maria Cella ${ }^{4}$ \\ Oldemir Carlos Mangili ${ }^{5}$ \\ AND Ives José SBALQUEIRO ${ }^{1}$
}

Spiders of the genus Loxosceles range about $15 \mathrm{~mm}$ in body length and have long and thin legs (FISCHER, 1996). Exhibit nocturnal and sedentary habits and inhabit quiet places, such as tiles, brick holes, wall cracks, underneath barks, and caves. Under favorable conditions, they can also be found frequently in homes, under blankets, clothes, inside shoes, behind wall pictures and in other similar

\footnotetext{
${ }^{1}$ Department of Genetics, SCB, Universidade Federal do Paraná; ${ }^{2}$ Undergraduate Scholarship of Scientific Initiation (UFPR-TN); ${ }^{3}$ Department of Basic Pathology, SCB, UFPR; ${ }^{4}$ Department of Biology, UNESP-Rio Claro (SP). ${ }^{5}$ Departament of Physiology, SCB, UFPR. Correspondence: Dr. Ives J. Sbalqueiro —Caixa Postal 19071 — 81531-970 _Curitiba, PR, Brasil. Email: ivesjs@ufpr.br.
} 
places. The genus Loxosceles includes a high number of species found worldwide. In South America, the estimation for number of species varies between 16 (BüCHERL, 1960) and 30 (GERTSH, 1967). Seven species of Loxosceles are found in Brazil: L. adelaida, $L$. amazonica, L. gaucho, L. hisurta, L. intermedia and L. laeta (GERTSCH, 1967). The last two species are common in southern region of the country, especially in Curitiba and its surroundings (MANFREDINI et al., 1993).

Loxosceles species are commonly known as "brown spiders", due to its color. In the epidemiologic aspect, Curitiba has a wide dissemination of brown spiders, with predominance of $L$. intermedia (MANFredini et al., 1993; Coutinho, 1996).

In this city, the "Loxoscelism" [the term describing lesions and reactions induced by bites of these spiders], represents an increasing problem of public health. Up to 3,000 accidents were notified by the health service institutions along the year of 2002 (VETTORELLO, 2002) (Fig. 1). The great majority of the accidents occurs when the spider is squeezed against the body of the victim.

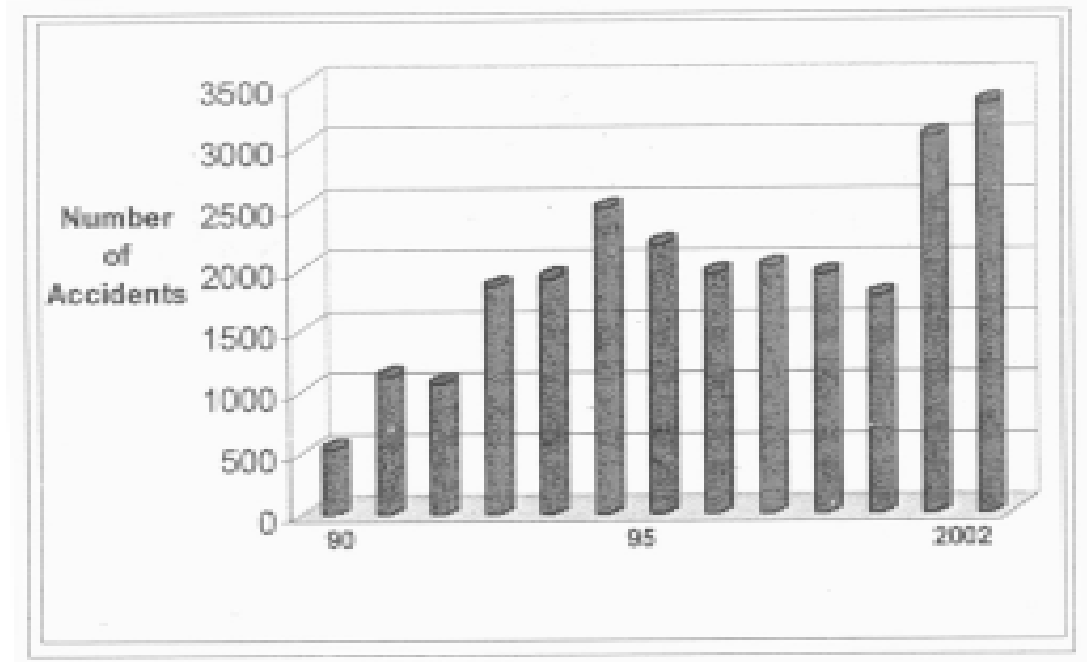

Fig. 1. Epidemic profile of the accidents with Loxosceles sp in Curitiba, Paraná - Brazil (1993-2002). [Reference: 1990-1992 — Secretaria de Estado de Saúde-PR (SESA - PR); 1993-2002 — Centro de Epidemiologia-Secretaria Municipal de Saúde (SMS) — Curitiba, PR] 
Although these spiders do not show any aggressive behavior, their venom may induce severe disorders on the human body (Rosenfeld et al., 1957; CARDoso et al., 1990; Veiga et al., 2001). The venom causes hemorrhage and dermonecrosis at the site of bite (Fig. 2), but other systemic effects also occur such as haemolysis, thrombocytopenia, dissemined intravascular coagulation and renal failure (Denny et al., 1964; Coutinho, 1996; Veiga et al., 1999; MonTEIRO et al., 2002).

In some cases, when the ulcerations produced by brown spider venon are extensive, plastic surgery has been recommended for the compromised dermonecrotic areas (BARBARO et al., 1992).

Cytogenetic studies in spiders of genus Loxosceles are rare. In $L$. rufipes and $L$. rufescens, the same diploid number $(2 \mathrm{n}=20)$ was found (BЕ̧̧AK \& BEÇAK, 1960; Dias \& SAĖz, 1965, 1966). These two species correspond probably to $L$. gaucho and $L$. laeta, respec-

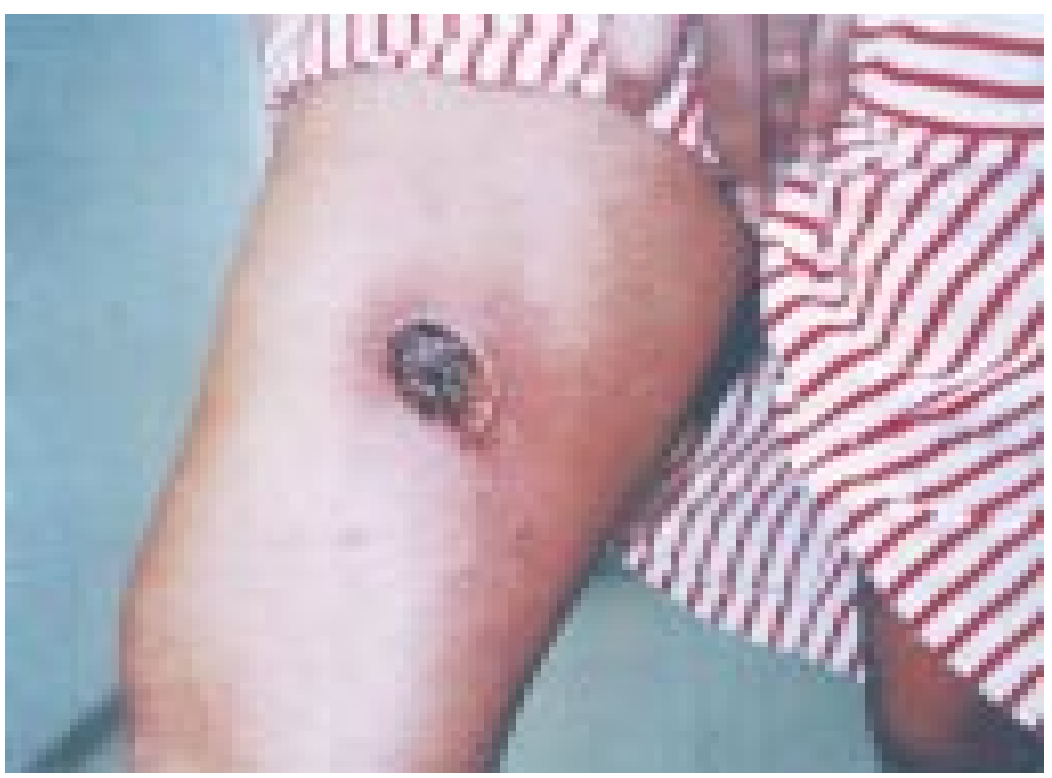

Fig. 2. Dermonecrotic lesion characteristic of the accident with Loxosceles spiders . [Picture gently yielded by Dr ${ }^{a}$ Marlene Entres.] 
tively, in the current nomenclature. In addition, the diploid number of $L$. reclusa was described by Tugmon et al. (1990): $2 \mathrm{n}=18, \mathrm{X}_{1} \mathrm{X}_{2}$ in males and $2 n=20, X_{1} X_{1} X_{2} X_{2}$ in females. A difference between the diploid number of males and females was also found in L. laeta from Lima (Peru), which showed $2 n=23$ in males and $2 n=24$ in females (SiLva, 1988). The same karyotypes were observed in L. laeta occuring in São Paulo (Brazil) (OliveIRA, 1998), with a multiple chromosome sex determination system of the type $\mathrm{X}_{1} \mathrm{X}_{2} \mathrm{Y} / \mathrm{X}_{1} \mathrm{X}_{1} \mathrm{X}_{2} \mathrm{X}_{2}$. L. gaucho showed a similar karyotype, with the same sex determination system (Oliveira et al., 1996; Oliveira, 1998).

In this study, the karyotypes of $L$. intermedia and $L$. laeta, through conventional and $\mathrm{C}$ banding techniques, in mitotic and meiotic chromosomes, are analyzed in order to contribute to a better understanding of the chromosomal diversity and reproductive biology of this group.

\section{MATERIAL AND METHODS}

Adult individuals of $L$. intermedia and L. laeta were collected in houses in Curitiba (PR, Brazil) or provided by the Laboratório Interdisciplinar de Pesquisa em Animais Peçonhentos (LIPAPE) (Setor de Ciências Biológicas, UFPR, Curitiba, PR). Cytological preparations were obtained from testis of adult males (meiotic and pre-meiotic cells) and from embryos (mitotic cells), according to WeBB et al. (1978). Chromosomes were stained with Giemsa for analysis of diploid number and chromosomal morphology. C-banding was carried out according to SUMNER (1972). Slides were analyzed, and the best preparations were selected. The photomicrographies were taken in a ZEISS microscope.

\section{RESULTS}

Pre-meiotic cells of Loxosceles intermedia showed 23 chromosomes in metaphase, with 10 homomorphic pairs and three heteromorphic chromosomes, which corresponded to $\mathrm{X}_{1}, \mathrm{X}_{2}$ and $\mathrm{Y}$ (Fig. 3 ). This conclusion was confirmed by the presence of 12 homomorphic pairs in embryonic cells. All the chromosomes of the complement were biarmed, including the Y, which the smallest chromo- 
some of the complement and its morphology is submetacentric.

The karyotype of L. laeta was very similar to the one described for males of L. intermedia (Fig. 4). The analysis of cells in diakinesis-metaphase I in spermatocytes (MI), in both species, revealed the presence of 10 autossomic bivalents and a sexual trivalent (Fig. 5). These findings confirmed the occurrence of a multiple chromosome sex system in both species. The Y chromosome is clearly visible. Figures $5 \mathrm{a}$ and $5 \mathrm{~b}$ show the associations between $\mathrm{X}_{1}, \mathrm{X}_{2}$ and $\mathrm{Y}$ in L. intermedia and L. laeta, respectively. Pairing occur through the terminal region of $X_{1}, X_{2}$ and $Y$ (Fig. 5c).

$\mathrm{C}$ banding analysis revealed different patterns in the two species. Hence, while conspicuous blocks of pericentromeric constitutive heterochromatin were observed in only a few pairs of $L$. intermedia chromosomes (Fig. 6a-c), they are found in all the chromosomes of L. laeta (Fig. 6b-d). In both species, these blocks are found in $\mathrm{X}_{1}$ and $\mathrm{X}_{2}$, while the $\mathrm{Y}$ chromosome is almost totally heterochromatic. Figures $6 \mathrm{c}$ and $6 \mathrm{~d}$ show the $\mathrm{C}$ banding patterns in pre-meiotic cells of $L$. intermedia and $L$. laeta, respectively.

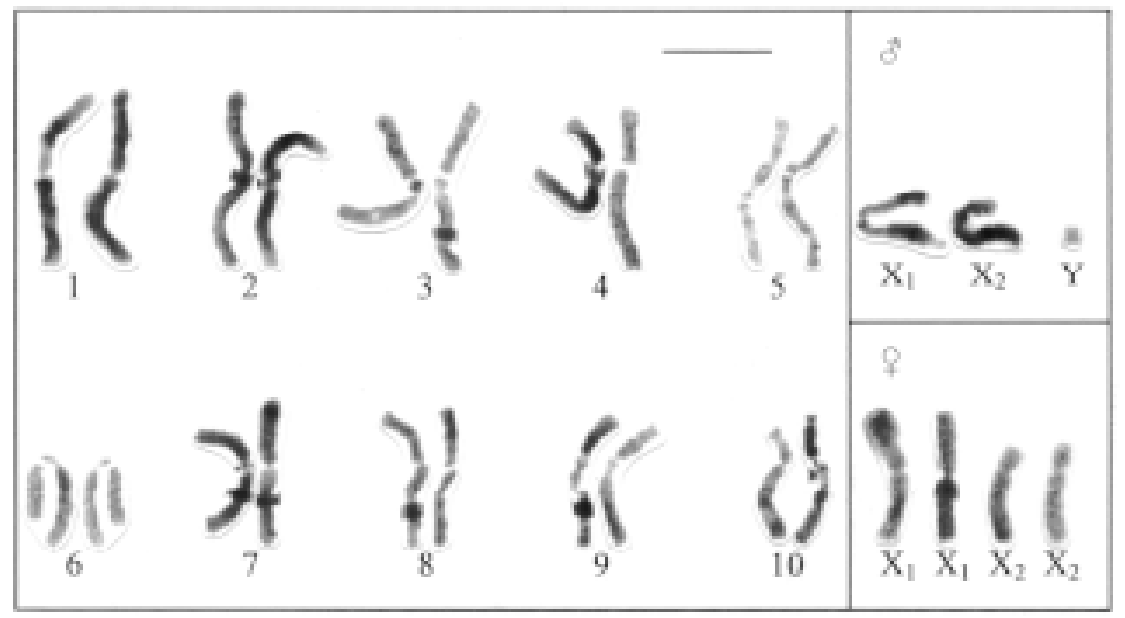

Fig. 3. Karyogram of L. intermedia standing out the sex chromosomes $\mathrm{X}_{1} \mathrm{X}_{2} \mathrm{Y}$ (male) and $\mathrm{X}_{1} \mathrm{X}_{1} \mathrm{X}_{2} \mathrm{X}_{2}$

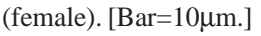




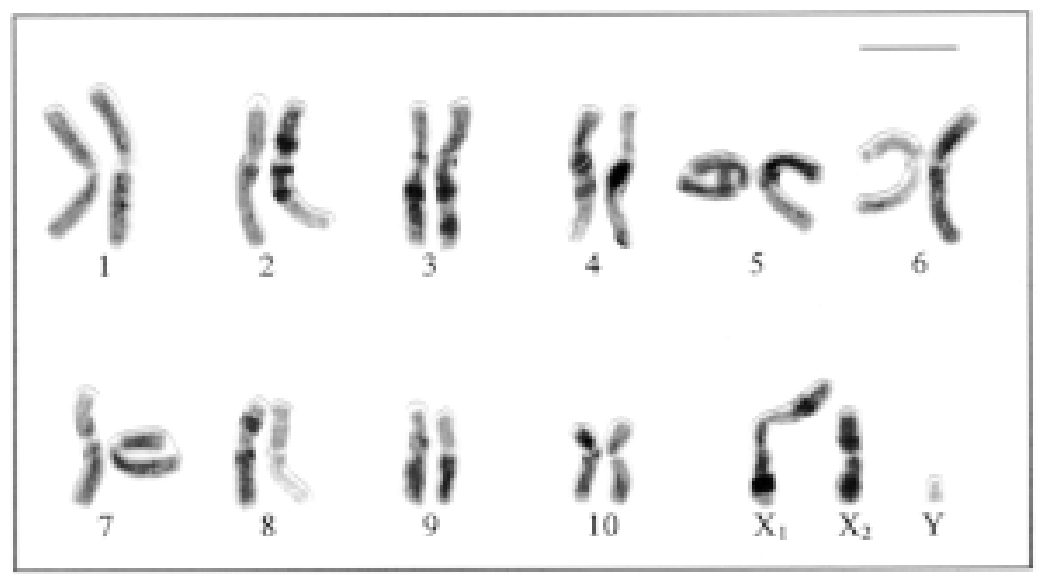

Fig. 4. Karyogram of adult male of L. laeta. [Bar $=10 \mu \mathrm{m}]$

\section{DISCUSSION}

Comparative cytogenetic analysis between males of L. laeta and L. intermedia, showed similar karyotypes, composed of biarmed autosomes and three heteromorphic chromosomes, which correspond to $\mathrm{X}_{1}, \mathrm{X}_{2}$ and $\mathrm{Y}$. In both species, the $\mathrm{Y}$ was the smallest chromosome of the complement. On the other hand, 12 pairs of homomorphic chromosomes were observed in embryonic cells of L. intermedia, probably corresponding to a female karyotype. Hence, the chromosome sex determination system revealed to be multiple, $\mathrm{X}_{1} \mathrm{X}_{2} \mathrm{Y} / \mathrm{X}_{1} \mathrm{X}_{1} \mathrm{X}_{2} \mathrm{X}_{2}$ /in both species.

Our data confirm previous studies in L. intermedia and L. laeta (Silva, 1988, Oliveira, 1998). However, these studies only infered the female karyotype. Hence, this study describes the karyotype of females of $L$. intermedia for the first time.

The karyotypes of the two species analyzed were very similar to the one of L. gaucho, concerning the diploid number and the sex chromosome determination system. However, L. gaucho had two pairs of acrocentric chromosomes (OliveIRA et al., 1996, Oliveira, 1998). Probably, this difference is the result of pericentric inversions.

From around 38,000 species of spiders (order Aranae) described 
so far, only $1 \%$ have been analyzed cytogenetically, with chromosomal morphology, diploid number and sex chromosome determination systems described (OliveIRA, 1998). In the majority of these karyotypes (around $72 \%$ ), the sex chromosome determination system found corresponds to the type $\mathrm{X}_{1} \mathrm{X}_{1} \mathrm{X}_{2} \mathrm{X}_{2} / \mathrm{X}_{1} \mathrm{X}_{2} \mathrm{Y}$. Variations found in other systems occur due to a variation in the number of $\mathrm{X}$ chromosomes, which can evolve as products of translocation events

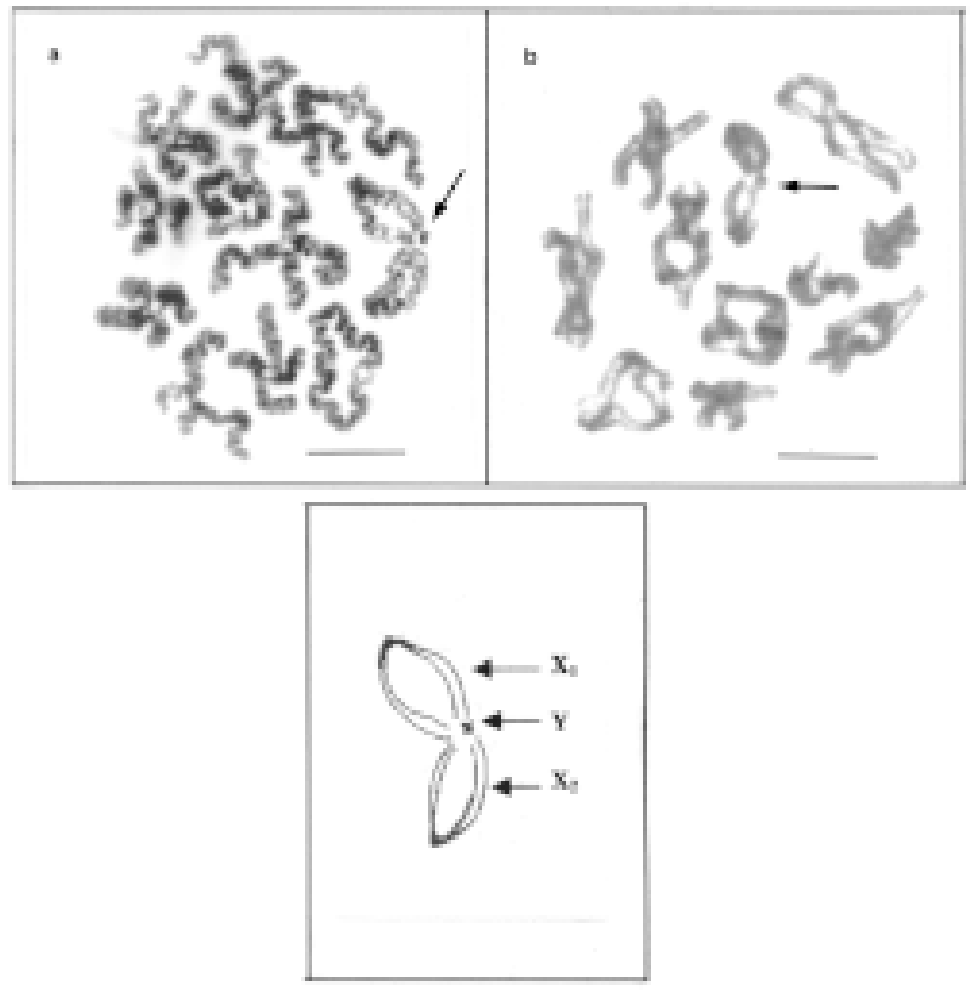

Fig. 5. Primary spermatocyte at diakinesis-metaphase-I: a) L. intermedia; b) L. laeta and c) Schematic diagram of sex trivalent. Arrow shows the sex trivalents in both species. [Bar=10 $\mu \mathrm{m}]$ 


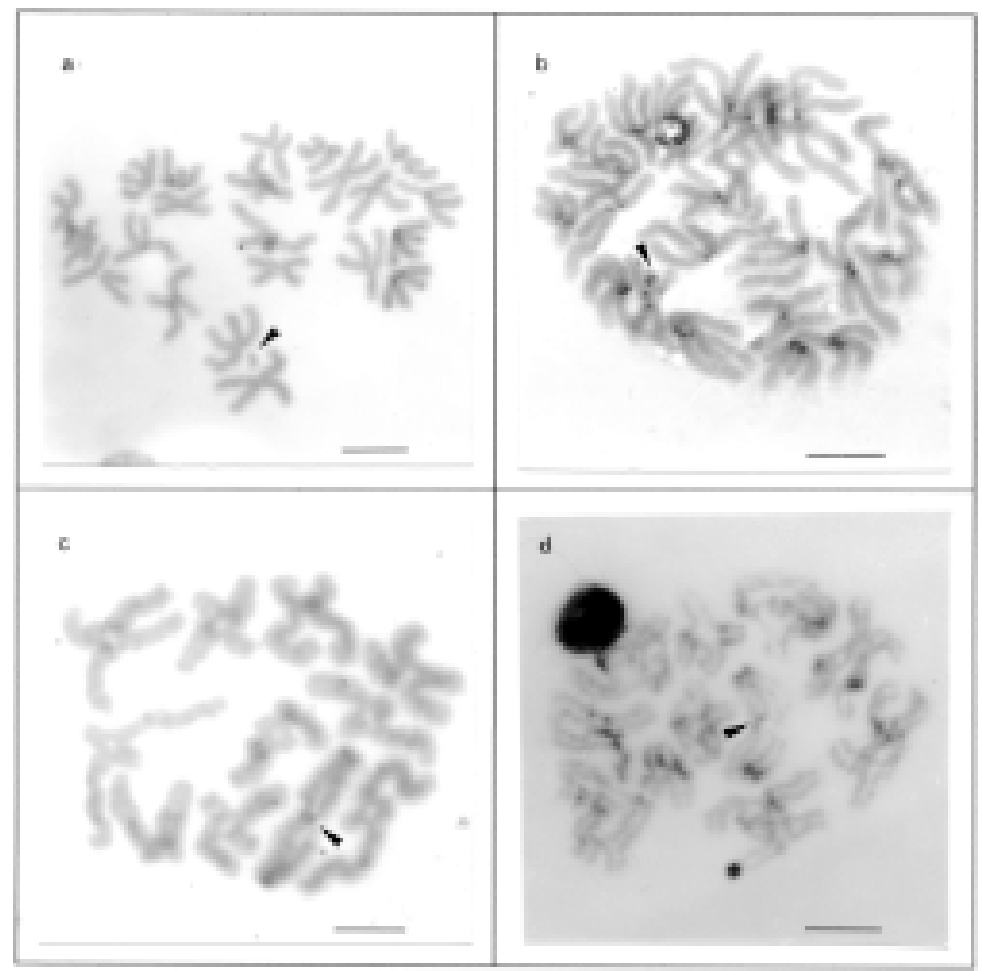

Fig. 6. C- banding: a) metaphase of L. intermedia; b) metaphase of L. laeta; c) diakinesis-metaphaseI of $L$. intermedia and d) diakinesis- metaphase-I of L. laeta. Arrow shows the Y chromosome. [Bar=10 $\mu \mathrm{m}]$

between the $\mathrm{X}$ and autosomes. Moreover, the number of $\mathrm{X}$ chromosomes in males corresponds to half of the number found in females. In the karyotypes of Loxosceles species (which correspond to less than $1 \%$ of the karyotypes analyzed so far), males presenting a $\mathrm{Y}$ chromosome are described in three of the four species analyzed: L. intermedia, L. laeta and $L$. gaucho, while $L$. reclusa with $X_{1} X_{2}$ in males and $X_{1} X_{1} X_{2} X_{2}$ in females (Oliveira, 1998). These data suggest that the system $\mathrm{X}_{1} \mathrm{X}_{2} \mathrm{Y} / \mathrm{X}_{1} \mathrm{X}_{1} \mathrm{X}_{2} \mathrm{X}_{2}$ derived from a sys- 
tem $X_{1} X_{2} / X_{1} X_{1} X_{2} X_{2}$, found in most of the analyzed species of spiders, is probably due to the mechanisms involving the original $X$ and autosomes, such as translocations.

This study presents, for the first time, the results of C-banding technique in spider chromosomes. The patterns of distribution of constitutive heterochromatin found in L. intermedia and L. laeta were clearly different, being an important cytological difference distinguishing them karyotypically. In both species, the Y chromosome is conspicuously marked. The submetacentric morphology and small size of this chromosome suggest a common evolutionary history of these two species.

The findings described in this study, concerning important chromosomal characteristics, demonstrate the importance of applying karyological studies in other species of spiders, which can reveal differential characters to improve taxonomic identification of taxons in this group.

\section{SUMMARY}

The genus Loxosceles includes cosmopolitan small spiders, which have nocturnal and non-agressive habits. Two species of brown spiders are found in the metropolitan area of Curitiba: L. intermedia and $L$. laeta. The first one is more abundant, and responsible for many accidents (Loxoscelism). The aim of this study is to analyze cytogenetically these spiders, through conventional (Giemsa) and c-banding techniques in pre-meiotic, meiotic and embrionary cells. The specimens were collected in houses or kindly provided by Laboratório Interdisciplinar de Pesquisa em Animais Peçonhentos (LIPAPE). Cytological preparations were obtained from embrionic cells or from testis of adult specimens. The data showed that both species are karyotipically similar, and had different diploid numbers in males and females ( $2 n=23$ and $2 n=24$, respectively). This difference is the result of a multiple sex chromosome system $\left(\mathrm{X}_{1} \mathrm{X}_{2} \mathrm{Y} /\right.$ $\mathrm{X}_{1} \mathrm{X}_{1} \mathrm{X}_{2} \mathrm{X}_{2}$ ). The use of c-banding technique revealed that a few chromosomes of $L$. intermedia showed pericentromeric blocks of 
constitutive heterochromatin, including gonosomes $\mathrm{X}_{1}$ and $\mathrm{X}_{2}$. On the other hand, all the chromosomes of L. laeta showed conspicuous pericentromeric $\mathrm{C}$-positive segments. In both species, the $\mathrm{Y}$ chromosome revealed to be almost tottaly heterochromatic. This study described the result of the use of c-banding technique for the first time in Loxosceles, which revealed an important karyotypical distintion between L. intermedia and L. laeta.

KEY WORDs: Loxosceles, brown spider, karyotype, c-banding.

\section{RÉSUMÉ}

Les araignées du genre Loxosceles sont petites, présentent une distribution cosmopolite, ont des habits nocturnes et ne sont pas agressives. Dans la region métropolitaine de Curitiba, on y trouve deux espèces de l'araignée marron: $L$. intermedia et $L$. laeta. La premiere c'est la plus abondante et responsable, dans les dernières années par des nombreux accidents connus sous le nom de loxoscelisme. Le but de cet article est celui d'étudier la cytogénétique de ces araignées, par moyen des colorants ordinaires dont le Giemsa et par le technique du bandage $\mathrm{C}$ en utilisant des cellules $\mathrm{C}$, des cellules pré-meyotiques, meyotiques et embryonnaires. Des échantillons ont été soit obtenues dans des maisons particulières, soit fournies par le Laboratório Interdisciplinar de Pesquisa em Animais Peçonhentos (LIPAPE), et les préparations cytologiques obtenues des testicules des adultes ou des cellules embryonnaires. Les résultats montrent que les deux espèces sont similaires du point de vue caryotype et se caractérisent par avoir un numéro diploíde différencié entre les sexes : 2 n=23 dans les mâles et 24 dans les femelles. Cette différence dans le numéro diploïde est due ao système chromosomique de détermination sexuelle - multiple du type $\mathrm{X}_{1} \mathrm{X}_{2} \mathrm{Y}$ (mâles) $/ \mathrm{X}_{1} \mathrm{X}_{1} \mathrm{X}_{2} \mathrm{X}_{2}$ (femelles). L'utilisation du bandage $\mathrm{C}$ a montré que chez $L$. intermedia pas beaucoup de chromosomes présentent la bande pericentrométrique, y compris les sexuels $X_{1}$ et $X_{2}$ Par contre, chez L. laeta, tous les chromosomes du génome présentent des bandes pericentrométriques visibles. Dans toutes les deux, le chromosome Y s'est montré presque hétérochromatique. Cet type 
de bandage, en plus d'inédite chez Loxosceles, s'est montré aussi important dans la séparation caryotypique entre $L$. intermedia et $L$. laeta.

Moтs CLÉs: Loxosceles, araignée-marron, caryotype, bandage C

\section{RESUMO}

As aranhas do gênero Loxosceles são pequenas, apresentam distribuição cosmopolita, hábitos noturnos e não agressivos. Na região metropolitana de Curitiba, são encontradas duas espécies de aranha marrom: L. intermedia e L. laeta. A primeira é a mais abundante e responsável, nos últimos anos, por inúmeros acidentes denominados de Loxoscelismo. O presente trabalho tem como objetivo estudar citogeneticamente estas aranhas, através de técnicas de coloração comum (Giemsa) e de bandeamento $\mathrm{C}$, em células prémeióticas, meióticas e embrionárias. Exemplares foram coletados em domicílios ou fornecidos pelo Laboratório Interdisciplinar de Pesquisa em Animais Peçonhentos (LIPAPE). As preparações citológicas foram obtidas a partir de testículos de aranhas adultas ou de células embrionárias. Os dados mostram que as duas espécies são cariotipicamente similares e caracterizam-se por apresentar um número diplóide diferenciado entre os sexos: $2 \mathrm{n}=23$ nos machos e 24 nas fêmeas. Esta diferença é devida ao sistema cromossômico de determinação sexual múltiplo, do tipo $\mathrm{X}_{1} \mathrm{X}_{2} \mathrm{Y}$ (machos) e $\mathrm{X}_{1} \mathrm{X}_{1} \mathrm{X}_{2} \mathrm{X}_{2}$ (fêmeas). A aplicação da técnica de bandeamento $\mathrm{C}$ revelou que em $L$. intermedia poucos cromossomos apresentam banda pericentromérica, incluindo os sexuais, $\mathrm{X}_{1} \mathrm{e} \mathrm{X}_{2}$, ao passo que em L. laeta, diferentemente, todos os cromossomos do genoma apresentaram bandas pericentroméricas conspícuas. Em ambas as espécies, o cromossomo Y mostrou-se quase que totalmente heterocromático. Este tipo de bandeamento, além de ser inédito em Loxosceles, revelou ser uma importante característica na diferenciação cariotípica entre $L$. intermedia e $L$. laeta.

Palavras Chave: Loxosceles, aranha-marrom, cariótipo, bandeamento C.

ACKNOWLEDGEMENTS - We thank Dr. Edivaldo H. C. de Oliveira for critical reading and review of the manuscript. We are also grateful to Dr. Carlos Kantek for writing the french summary and LIPAPE- 
UFPR for spider capture and growth cares. This research was supported by CNPq and Fellowship Program - Tesouro Nacional (UFPR).

\section{BIBLIOGRAPHY}

Barbaro, K. C.; J. L. Cardoso; V. R. D. Eickstedt \& I Mota. 1992.Dermonecrotic and lethal components of Loxosceles gaucho Spinder Venon. Toxicon 30: 331-338.

BeÇAK, W.; M. L. BeÇAK. 1960. Constituição cromossômica de duas espécies de aranhas do gênero Loxosceles. Rev. Bras. de Biol., 4 (20): 425-427.

Bücherl, W. 1960. A aranha Loxosceles e "Loxoscelismo". Ciênc. Cult. 12 (2): 84-85.

Cardoso, J. L. C.; Wen, F.H.; França, F. O. S.; Warrell, D. A.; Theapston, R. D. G. 1990. Detection by enzyme immunoassay of Loxosceles gaucho venom in necrotic skin lesions caused by spider bites in Brazil. Trans. R. Soc. Trop. Med. Hyg. 84: 608609.

Coutinho, N. L. R. 1996. Avaliação Funcional e Histopatológica das Alterações Renais Induzidas pelo veneno da "aranha marrom”, Loxosceles intermedia (Mello-Leitão, 1934). Dissertação Mestrado, SCB, UFPR (Curitiba) 98 pp.

Denny, W.F.; Dillaha, C.J.; P. N. Morgan. 1964. Hemotoxic effect of Loxosceles reclusa venom: in vivo and in vitro studies. J. Lab. Clin. Med., 64: 291-298.

DiAZ, M.; F. SAÉZ 1965. Investigaciones citogeneticas sobre algumas espécies de aranidos uruguayos. In: Congresso Latino Americano de Zoologia, II, São Paulo - SP. An. II Cong. Lat. Am. Zoo., p. 3-9.

Diaz, M.; F. SAÉZ. 1966. Karyotypes of South-American Araneida. Mem. Inst. Butantan, 1 (33): 153-154.

Fisher, M. L. 1996. Biologia e Ecologia de Loxosceles intermedia Mello-Leitão, 1934, (Araneae, Sicariidae), no Município de Curitiba, PR. Tese de Mestrado em Zoologia, SCB, UFPR, Curitiba 137 pp.

GerTsCh, W. J. 1967. The spider genus Loxosceles in south America 
(Araneae, Scytodidae). Bull. Am. Mus. Nat. Hist. 136 (3): $117-$ 174.

Manfredini, L.; E. M. C. P. Maluf; D. S. Carvalho; I. Opabe; O. C. Mangili. 1993. Loxosceles: A "aranha marrom". Cadernos de Saúde (Prefeitura da Cidade de Curitiba). 1 (2).

Monteiro, C.L.B.; R. Rubel; L. L. Cogo; O. C. Mangili; W. Gremski; S. S. VeIGA. 2000. Isolation and identification of Clostridium perfringens in the venom and fangs of Loxosceles intermedia (brown spider): enhancement of the dermonecrotic lesion in loxoscelism. Toxicon 40: 409-418.

Oliveira, E. G. 1998. Estudo Citogenético em 13 espécies de aranhas (Arachnida, Araneae) pertencentes às famílias Ctenidae,Lycosidae, Sicariidae e Theraphosidae. Dissertação de Mestrado, Instituto de Biociências, UNESP-Rio Claro. 177 pp.

Oliveira, E.G.; D. M. Cella; A. D. Brescovitt; C. R. Bertin. 1996. The karyotype of Loxosceles gaucho and Ctenus ornatus (Archnida, Araneae, Loxoscelidae, Ctenidae). Braz. J. Genet. (supl.) 19 (3) : 128.

Rosenfeld, G.; L. Nahas; D. M. Cillo; C. T. Fleury. 1957. Envenenamentos por serpentes, aranhas e escorpiões. In: Prado, F. C. Ed. Atualização Terapêutica.

SiLVA, D. D. 1988. Estudio cariotipico de Loxosceles laeta (Araneae: Loxoscelidae). Rev. Per. Ent. 31: 9-12.

Sumner, A. T. 1972. A simple technique for demonstrating centromeric heterochromatin. Exp. Cell Res. 75: 304-306.

Tugmon, C. R.; J. R. Brow; N. V. Horner. Karyotype USA spider (Araneae, Araneidae, Gnaphosedae, Loxoscelidae, Lycisidae, Oxyopidae, Philodromidae, Salticidae and Therediidae). J. Arachnol., 18: 41-48, 1990.

Veiga, S.S.; W. Gremski; V. L. P. dos Santos; L. Feitosa; O. C. Mangili; H. B. Nader; C. P. Dietrich; R. R. Brentani. 1999. Oligosaccharide residues of Loxosceles intermedia (brown spider) venom proteins: dependence on glycosylation for dermonecrotic activity. Toxicon 37: 587-607.

Veiga, S. S.; V. C. Zanetti; A. Braz; O. C. Mangili; W. Gremski. 2001. Extracellular matrix molecules as targets for brown spider 
venom toxins. Braz. J. Med. Biol. Res. 34: 843-850, 2001.

Vettorello, M. L. 2002. A influência da temperatura, umidade relativa do ar e radiação solar na incidência dos acidentes loxoscélicos em Curitiba, Paraná, Brasil, no período de 1998 a 2001. Monografia (Especialização em Epidemiologia de Vetores Importantes em Saúde Pública), Departamento de Patologia Básica, SCB, UFPR. Curitiba, 62 pp.

Webb, G. C.; M. J. D. White; N. Contreras; J. Cheney. 1978. Cytogenetics of the parthenogenetic grasshopper Warramaba (formely Maraba) virgo and its bisexual relatives. IV. Chromosome banding studies. Chromosoma 67: 309-39.

Recebido em: 29.XI.2002. 